\title{
Characterisation of weathered clayey soils responsible for shallow landslides
}

\author{
C. Meisina \\ Department of Earth Sciences, Pavia, Italy \\ Received: 6 June 2006 - Revised: 10 August 2006 - Accepted: 4 September 2006 - Published: 25 September 2006
}

\begin{abstract}
Shallow earth translational slides and earth flows, affecting colluvial soils derived by the weathering of the clayey bedrock, are a recurrent problem causing damage to buildings and roads in many areas of Apennines. The susceptibility assessment, e.g. slope stability models, requires the preliminary characterization of these superficial covers (lithology, geotechnical and hydraulic parameters).
\end{abstract}

The aim of the work is to develop and test a methodology for the identification and mapping of weathered clayey soils responsible for shallow landslides.

A test site in Northern Apennines (Province of Pavia) was selected. Argillaceous and marly successions characterize the area. Shallow landslides occurred periodically due to high intensity rainfalls. Trench pits were used for the soil profile description (lithology, structure, grade of weathering, thickness) and sampling. The main geological, topographic and geomorphologic parameters of shallow landslides were analysed. Field surveys were integrated with some geotechnical laboratory tests (index properties, suction and volumetric characteristic determination, methylene blue adsorption test, linear shrinkage, swell strain).

Engineering geological zoning was carried out by grouping the superficial soils on the basis of the following attributes: topographic conditions (slope angle), landslide occurrence, lithology (grain size), geometry (thickness), lithology of the bedrock, hydrogeological and geotechnical characteristics. The resulting engineering-geological units (areas that may be regarded as homogeneous from the geomorphologic and engineering - geological point of view) were analysed in terms of shallow slope instability.

Correspondence to: C. Meisina

(cmeisina@manhattan.unipv.it)

\section{Introduction}

In most part of the Italian Apennines the bedrock is represented by highly tectonized varicoloured clays and by flysch formations consisting of alternating layers of clay shales with calcareous arenaceous marls. Both represent structurally complex tectonized formations having a predominant argillaceous component (Esu, 1977). The processes of chemical alteration and physical breakdown result in the weathering of the bedrock and the production of thick sequences of weathered materials, generally consisting in clays, including diffused lapideous fragments of different size, with reduced physical and geotechnical properties. The degradation of the mechanical properties of the bedrock can be referred to processes concerning with water content changes, e.g. cycles of wetting-drying, softening (Picarelli, 2000), infiltration of different aqueous solutions (Calvello et al., 2005). Gravitational forces acting on these disaggregated materials cause them to move down and to accumulate on the slope (colluvial deposits), with the maximum thicknesses in the topographic depressions.

The most common slope instabilities in colluvium are an initial shallow rotational or translational slide followed by flowage of the disturbed mass (Turner, 1996). Shallow earth translational slides and earth flows, affecting the colluvial soils are a recurrent problem causing damage to buildings and roads in many areas of Apennines. In order to define the shallow landslide problem, it is essential to establish landslide-prone zones (landslide susceptibility assessment) and depict these zones on maps, which in turn will allow an effective land management.

The susceptibility assessment, e.g. slope stability models, requires the preliminary characterisation of the superficial covers (e.g. lithology, geotechnical parameters) and the selection of a mapping unit, a portion of the land surface containing a set of ground conditions which differ from the adjacent units across definable boundaries.

Published by Copernicus GmbH on behalf of the European Geosciences Union. 
The aims of the of the present work are:

- to develop and test a methodology for the identification and mapping of weathered clay soils responsible for shallow landslides;

- to determine geological, geomorphological and geotechnical characteristics of weathered clay soils associated to shallow landslides in order to identify mapping units called engineering - geological units (areas that may be regarded as homogeneous from the geomorphologic and engineering - geological point of view).

For these purposes a test site in Northern Apennines (Province of Pavia) was selected. It is characterized by clayey-silty colluvial soils on argillaceous bedrock (varicoloured clays and flysch) and by shallow landslide due to intense rainfalls.

\section{Study area}

The test site corresponds to the territory of Serra del Monte which is located in the western part of Oltrepo Pavese (Fig. 1). The Oltrepo Pavese, which is situated in Northern Italy, has an extension of about $1100 \mathrm{~km}^{2}$. Its Southern part corresponds to the northwestern sector of the Apennines. The area is at heights of between $200 \mathrm{~m}$ and $1725 \mathrm{~m}$ a.s.1. and it is characterized by a complex geological and structural setting.

The geology is dominated by sedimentary formations, with a dominant clay component (Beatrizzotti et al., 1969; Braga et al., 1985). Clay shales, referred to as Argille Varicolori (varicoloured clays), or Complesso Caotico (chaotic complex), outcrop throughout the Oltrepo Pavese area, while calcareous flysch, made up of alternating marls, calcareous marls, and scratched shales predominated in the eastern part. Sandstones slabs lying on a deformable clayey substratum are present as cap-rocks in the central part. Silty and/or clayey deposits formed by weathering and down slope transportation cover the argillaceous bedrock units.

The study site covers an area of $5 \mathrm{~km}^{2}$ and lies within the municipality of Cecima in the province of Pavia. In its upper part the area is characterized by sandstones (Monte Vallassa Sandstone) which act as hydrogeological reservoirs. The stability conditions of the slope are governed by the groundwater circulation in the sandstone, sustained by the underlying impermeable clayey and marly epi-ligurian and ligurian succession: Monte Lumello Marls (siliceous marls), Antognola Marls (hemipelagic marls), Monte Piano Marls (varicoloured clays), Zebedassi Limestone (calcareous turbidites). The water emerging at the surface and flowing down the hill cause the softening of the clayey soils and this contributes to the evolution of slope movements. Slopes in the argillaceous and marly successions are mantled with colluvial deposits varying between 1 and $6 \mathrm{~m}$ in thickness.
A land use map was established by photo-interpretation. Cultivation of alfalfa and corn covers about $70 \%$ of the region. Vineyard and forest cover the remaining areas.

The area has a mean annual rainfall of about $800 \mathrm{~mm}$ (Varzi rain gauge). The general annual rainfall pattern is characterized by a summer minimum in July and two maxima, in October-November and in May (Rossetti and Ottone, 1979).

\section{Method}

To identify and map colluvial soils, in the study area, specific parameters were selected in accordance with the mapping scale (1:10000) and the objectives of the work (identification of the engineering-geological units):

- topographic conditions (slope angle),

- landslide (particularly shallow slide) occurrence,

- lithology of the rock substrate,

- lithology (grain size) and structure of the colluvial soils,

- geometry of the colluvial soils (thickness),

- hydrogeological and geotechnical characteristics of the colluvial soils (value of bleu, plasticity index, swellingshrinkage potential, swell strain, linear shrinkage, active zone depth).

Engineering-geological unit is an area in which these parameters, obtained from both field and laboratory work, are assumed to be uniform. The identification of the engineeringgeological units was done into two steps. In the first step the landforms (preliminary units) were mapped. In the second step each landform was investigated through field surveys and laboratory tests in order to subdivide the landforms in engineering-geological units.

\subsection{Landform identification}

The landforms consisted on landslides and areas with different slope angle.

A 1:10000 scale landslide inventory map was produced using 1:25000 scale black-and-white aerial photographs, acquired in 1994. The photo-interpretation was validated through several field checks in 2000-2002, which allowed also to classify the slope movements in relation to the state of activity (active, dormant and inactive), following geomorphological criteria (e.g. hummocky topography, undrained depressions, well-defined surface features as landslide scarp, ground cracks for active landslides). The Cruden and Varnes (1996) criteria were adopted for the slope movement classification. The areas characterized by shallow landslides developed after the November 2002 strong rainfalls were also identified. 


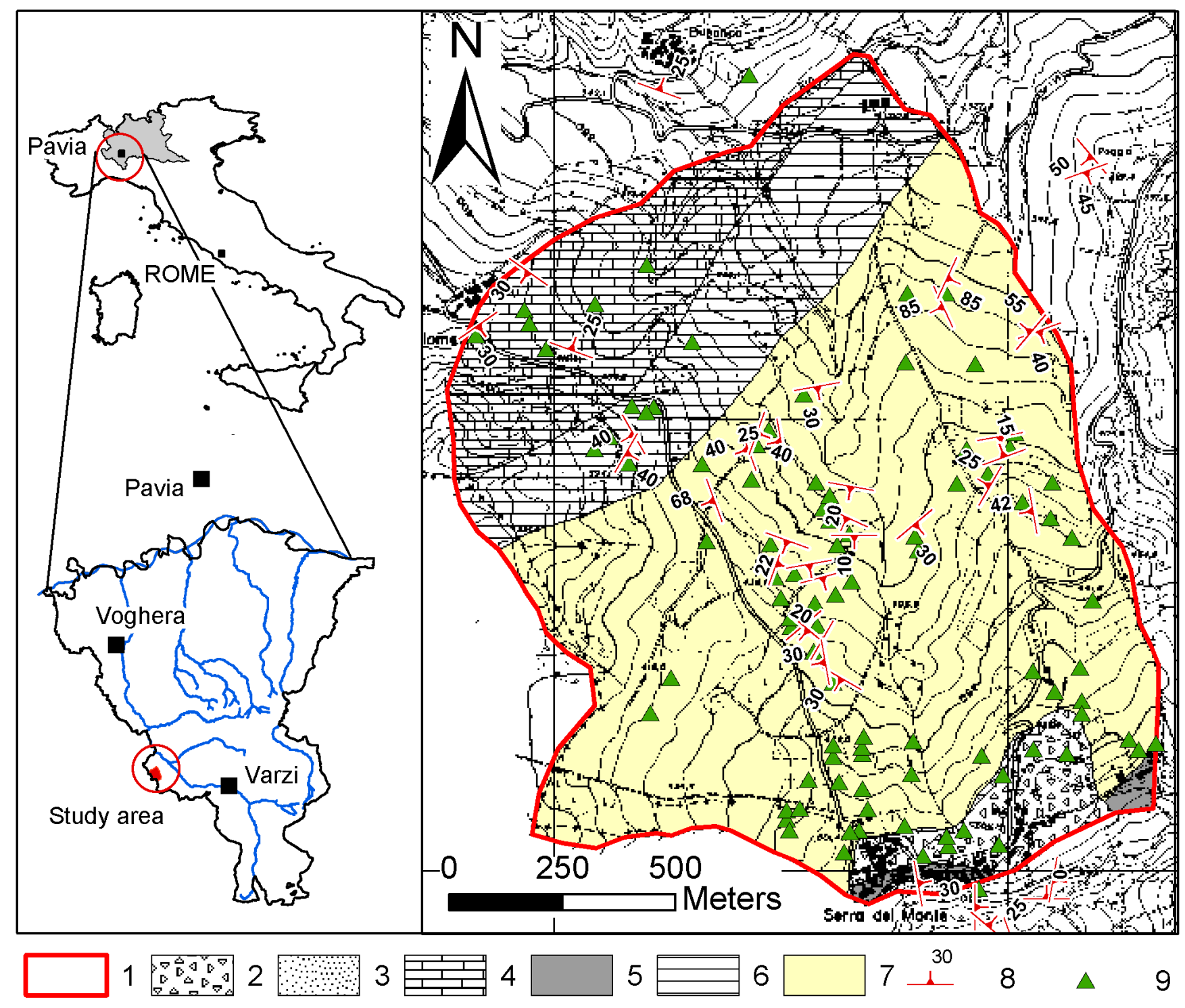

Fig. 1. Geological sketch of the study area. 1: study area; 2: talus debris; 3: Monte Vallassa Sandstone (Tortonian-Serravallian); 4: Monte Lumello Marls (Langhian- pre-Langhian Miocene); 5: Antognola Marls (pre-Langhian Miocene-Upper Oligocene); 6: Monte Piano Marls (Eocene); 7: Zebedassi Limestone (Paleocene-Turonian); 8: bedrock strata attitude (the number indicates the dip angle); 9: trench pit.

The study zone was firstly divided in two areas depending upon the presence or absence of landslides. These areas were then subdivided on the basis of the slope angle calculated from a DEM which was derived from a 1:10 000 scale contour map, with a resolution of the topographic data of $10 \mathrm{~m}$. Four classes of slope angle were defined: $<6^{\circ}, 6^{\circ}-$ $12^{\circ}, 12^{\circ}-20^{\circ}$ and $>20^{\circ}$.

\subsection{Engineering-geological unit identification}

Site investigation and laboratory tests allowed to obtain for each landform the parameters (lithology of the rock substrate, lithology, thickness, structure, hydrogeological and geotechnical characteristics of the colluvial soils) used for the identification of the engineering-geological units. Landforms with large variation of these properties were subdivided in more uniform units, called engineering-geological units; landforms with a certain degree of homogeneity became directly engineering-geological units.

The "colluvial soil thickness" parameter plays an important role in the study of shallow slope instabilities (e.g. infinite slope stability models), therefore the engineeringgeological units were divided into different subunits in relationship with the thickness of the colluvial material. 


\subsubsection{Site investigation}

Site investigations were made aiming at characterising the soil colluvium and the bedrock within each landform. A detailed stratigraphical description was also carried out: weathered soil profile description, also in correspondence of landslide bodies; bedrock characterisation; the presence or absence of ground-water seeps was also recorded. The soil profile was established on the basis of a limited number of outcrops and more than 100 trench pits and trench drains with a mean depth of 5-6 m (see Fig. 1 for the location). During the site investigation, samples for laboratory tests were also collected.

The colluvium thickness was evaluated by grouping it into 4 classes $(<2 \mathrm{~m} ; 2-3 \mathrm{~m}, 3-4 \mathrm{~m}$ and $>4 \mathrm{~m})$ which led to a colluvial thickness map.

A particular attention was paid to the swelling-shrinking characteristics of the soils (slickensides, shrinkage cracks), which play an important role in predisposing the shallow instabilities. A quantitative description of the crack patterns at the soil surface was done in different sites corresponding to natural soils and to soils ploughed during the previous spring. This description is aimed at quantifying the influence of the shrinkage on shallow instabilities in relationship also with the land use. Crack depth and thickness were measured in order to determine the horizontal shrinkage. Site investigations were conducted in August-September 2003, when the region suffered an intense drought period which started in April 2003 and ended in November 2003.

To determine the maximum active zone depth (zone of seasonal moisture content variation) the values of the matric suction were determined on samples collected during AugustSeptember 2003 (dry season) by the filter paper technique (Chandler and Gutierrez, 1986; ASTM, 1994; Swarbrick, 1995).

The samples were taken vertically each $0.5 \mathrm{~m}$ in colluvial material. The samples consisted of hand-prepared undisturbed blocks and disturbed bag samples, all obtained from shallow trench pits.

\subsubsection{Laboratory tests}

A series of laboratory tests was conducted in order to define the main physical and mechanical characteristics of the colluvial soils. All tests were performed according to ASTM specifications (American Society for Testing and Materials, 1994). The tests performed included the natural water content, unit weight, degree of saturation, grain size distribution, Atterberg limits (liquid, plastic and shrinkage limits). The results of grain-size distribution and Atterberg limits tests were used to classify the colluvial soils according to the Unified Soil Classification System (USCS). In addition to the classical geotechnical tests (index properties and volumetric characteristic determination) the samples were submitted to the methylene blue adsorption test, which allows an estima- tion of the type of clay mineral. The methylene blue dye adsorption ("value of blue" $\mathrm{Vb}$ ) was determined in accordance with the French AFNOR standards (AFNOR, 1998). This method is based on the adsorption of methylene blue dye by clay minerals. Methylene blue dye in aqueous solution dissociates into anion chloride and methylene blue cation. This cation displaces $\mathrm{Na}^{+}, \mathrm{Ca}^{2+}, \mathrm{K}^{+}$and $\mathrm{Mg}^{2+}$ cations allowing the determination of the specific surfaces $(\mathrm{Sa})$ of these minerals (Magnan and Youssefian, 1989; Chiappone and Scavia, 1999).

The one-dimensional swell strain was measured with the loaded-swell test in the oedometer cell on samples collected during August-September 2003. The specimen was loaded to a vertical stress of $12.5 \mathrm{kPa}$ (equivalent to the in situ overburden pressure) and then flooded with water and allowed to swell. Readings were taken until full swell was attained. The increase in vertical height of a sample, expressed as a percentage, due to an increase in moisture content, was designated as the swelling strain.

\section{Slope instability}

The slopes are subjected to widespread instability (Fig. 2); landslides developed in the years 1976-1978, due to high intensity rainfalls, and reactivated in 1993, 1996, 2000 and 2002. Different types of slope instability are present: most of the landslides occurred in the Zebedassi Limestone and belong to complex mass movements, which combine slide (translational) and flow mechanisms (Cruden and Varnes, 1996). Earth flows are located in the western part of the area and developed in the Varicoloured Clays of the Monte Piano Formation and in Zebedassi Limestone. Translational slides are generally deeper seated and larger, they involve the bedrock (marls and clay with limestone and marly calcareous intercalations) and are typical of the Monte Lumello Marls. Larger landslide bodies mapped in Fig. 2, involving the Zebedassi Limestone, indicate areas where many small instability phenomena are recurrently present. Shallow landslides are widespread and they involve clayey colluvial soil during heavy rainfall events as in October 1993, October-November 2000 and November 2002. The cumulative rainfalls for a 60 day period before the events were equal respectively to 450,350 and $300 \mathrm{~mm}$. These heavy rainfall events followed intense drought periods such as March 1989-August 1993; May 1998-September 2000, June 2001October 2002 (Meisina, 2004).

The identification and mapping of the shallow landslides is difficult due to their small size, and to the intensive farming activity. Field observations in 2000 and 2002, after strong rainfall events, indicated that most of the failure surfaces are located along the contact between the colluvium and the partially weathered or unweathered bedrock. The most frequent types are complex (translational slides associated with earth flows) and they develop on the Zebedassi Limestone. A 


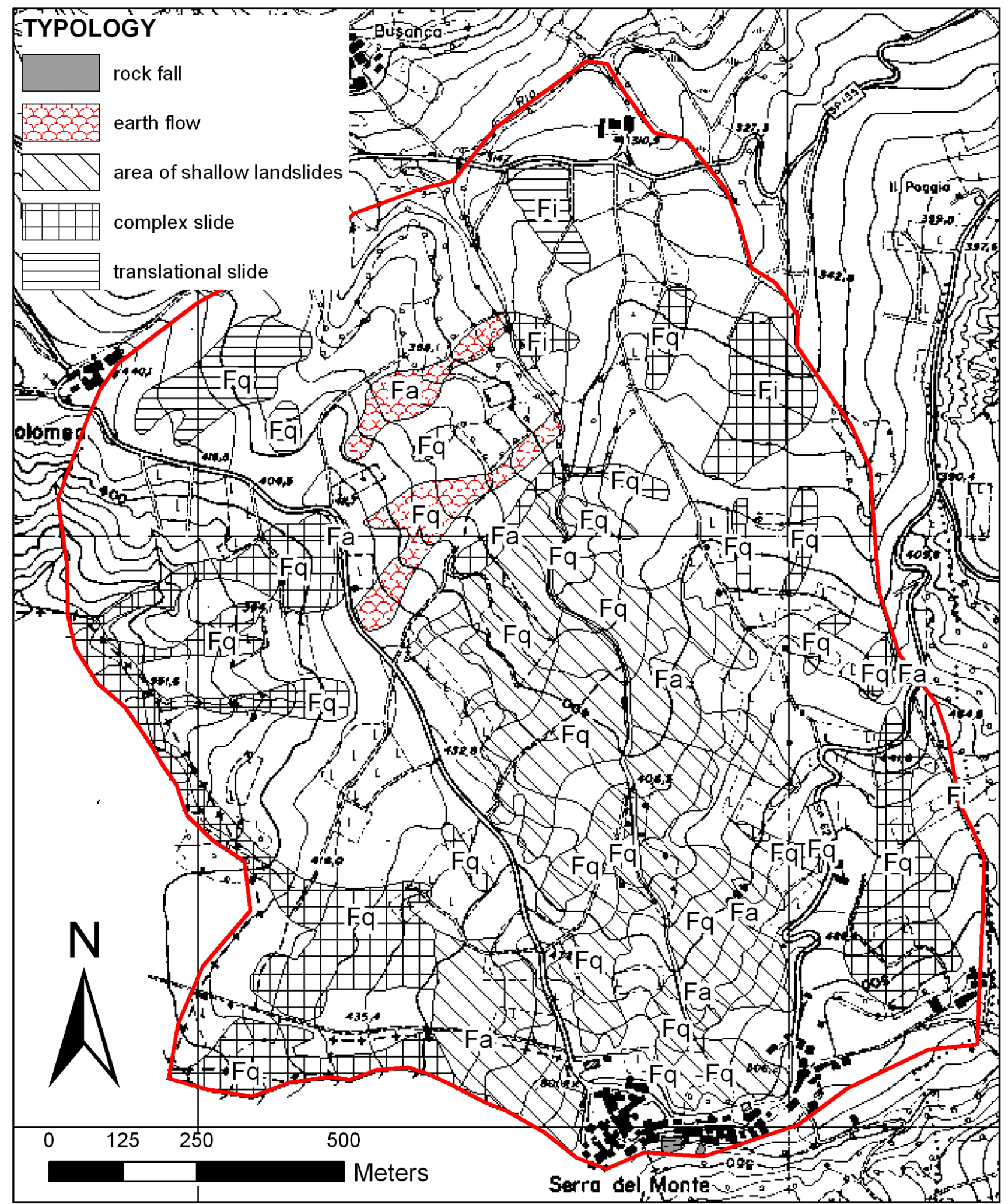

Fig. 2. Landslide-inventory map (For the keys to legend, see Sect. 5, Fa: active landslide; Fq: dormant landslide; Fi: inactive landslide). 
Table 1. Characteristics of the engineering geological units (A: slope angle, T: thickness, Z: active zone depth).

\begin{tabular}{|c|c|c|c|c|c|c|}
\hline Units & Sub-units & Grain size & $\mathrm{A}\left({ }^{\circ}\right)$ & $\mathrm{T}(\mathrm{m})$ & $\mathrm{Z}(\mathrm{m})$ & Bedrock \\
\hline \multirow[t]{2}{*}{$\mathrm{sd}$} & & - & $>20$ & $<0.5$ & - & $\begin{array}{l}\text { Sandstone (M. Vallassa Sand- } \\
\text { stone) }\end{array}$ \\
\hline & $\operatorname{sn} 0$ & & & $0-2$ & & Debris from M. Vallassa \\
\hline \multirow[t]{3}{*}{ sn } & & Sandy silt & $12-20$ & & $<0.8$ & Sandstone \\
\hline & sn1 & & & $2-3$ & & \\
\hline & $\operatorname{sn} 2$ & & & $3-4$ & & \\
\hline \multirow[t]{2}{*}{ snf } & snf1 & $\begin{array}{l}\text { Sandy clayey silt (landslide } \\
\text { material) }\end{array}$ & $12-20$ & $2-3$ & $<0.8$ & $\begin{array}{l}\text { Debris from M. Vallassa } \\
\text { Sandstone }\end{array}$ \\
\hline & $\operatorname{snf} 2$ & & & $3-4$ & & \\
\hline \multirow{4}{*}{$\mathrm{cl}$} & $\mathrm{cl0}$ & Silty clay and clayey silt & & $0-2$ & 1.2 & \\
\hline & & $\begin{array}{l}\text { with calcareous nodules and } \\
\text { marly fragments }\end{array}$ & $6-12$ & & & Zebedassi Limestone \\
\hline & cl1 & & & $2-3$ & 1.9 & \\
\hline & $\mathrm{cl} 2$ & & & $3-4$ & 2.5 & \\
\hline \multirow{5}{*}{ clf } & clf0 & Silty clay and clayey silt with & & $0-2$ & 1.2 & \\
\hline & & material) & $6-12$ & & & Zebedassi Limestone \\
\hline & clf1 & & & $2-3$ & 1.4 & \\
\hline & $\operatorname{clf} 2$ & & & $3-4$ & 2.5 & \\
\hline & clf3 & & & $>4$ & 2.5 & \\
\hline \multirow{4}{*}{ sl } & sl0 & Clayey silt with marly frag- & & $0-2$ & 0.8 & \multirow{4}{*}{ M. Lumello Marls } \\
\hline & & ments & $6-12$ & & & \\
\hline & sl1 & & & $2-3$ & 12 & \\
\hline & $\mathrm{s} 12$ & & & $3-4$ & 1.2 & \\
\hline \multirow{4}{*}{ slf } & slf0 & $\begin{array}{l}\text { Clayey silt with marly frag- } \\
\text { ments (landslide material) }\end{array}$ & & $0-2$ & 0.8 & \multirow{4}{*}{ M. Lumello Marls } \\
\hline & slf1 & & $6-12$ & $2-3$ & & \\
\hline & slf2 & & & $3-4$ & 1.2 & \\
\hline & slf3 & & & $>4$ & & \\
\hline \multirow{2}{*}{ scl } & scl1 & Varicoloured clay & $6-12$ & $2-3$ & 12 & \multirow{2}{*}{ M. Piano Marls } \\
\hline & $\mathrm{scl} 2$ & & 612 & $3-4$ & & \\
\hline sclf & sclf1 & Varicoloured clay & $6-12$ & $2-3$ & 1.2 & M. Piano Marls \\
\hline
\end{tabular}

minor number of shallow slides are represented by earth flow (M. Piano Marls and Zebedassi Limestone) and by translational slides (M. Lumello Marls). Remediation works consist of trench drains.

\section{Results}

\subsection{Colluvial soil lithology and structure}

Nine engineering-geological units were identified. The characteristics of the colluvial soils and the underlying bedrock material for each engineering geological unit are summarized in Table 1 and Figs. 3-4.
Unit sd corresponds to the Monte Vallassa Sandstone: slope angles are up to $20^{\circ}$, and therefore colluvial material is very thin $(<0.5 \mathrm{~m})$.

Unit sn corresponds to the debris cover (sandy-clayey silt with coarse arenaceous fragments), thick less than 2-3 m, deriving from the weathering of the sandstone. Unit snf corresponds to landslide material involving the debris cover. The units sd and sn cover only $5 \%$ of the territory and they are present in the southern part of the area, near the village of Serra del Monte; a limited number of shallow landslides developed in this unit. Field observations indicated that sliding occurred along the soil-bedrock contact, and was translational in nature. 


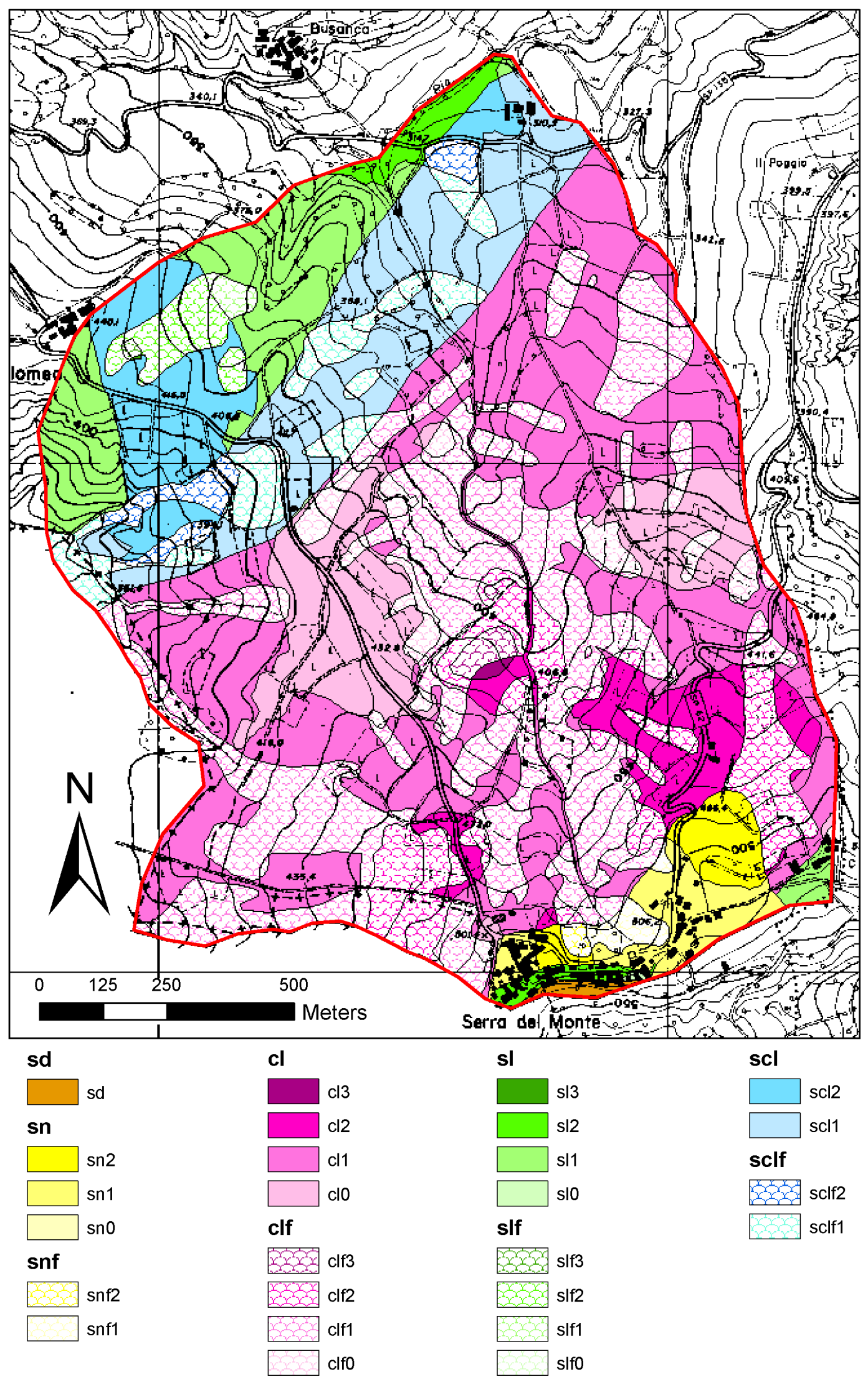

Fig. 3. Engineering geological unit map (see Table 1 for the description of the engineering-geological units). 


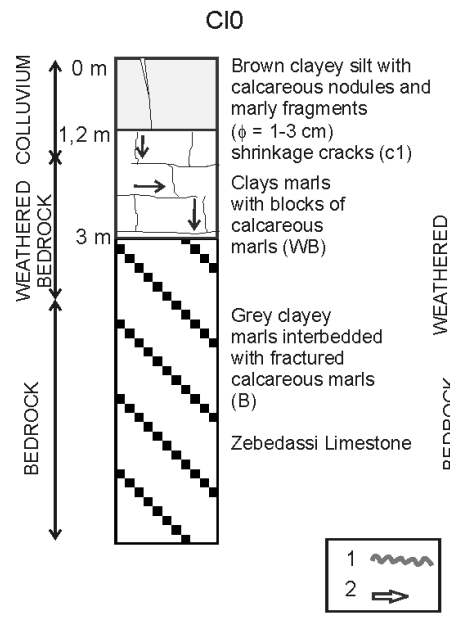

SI

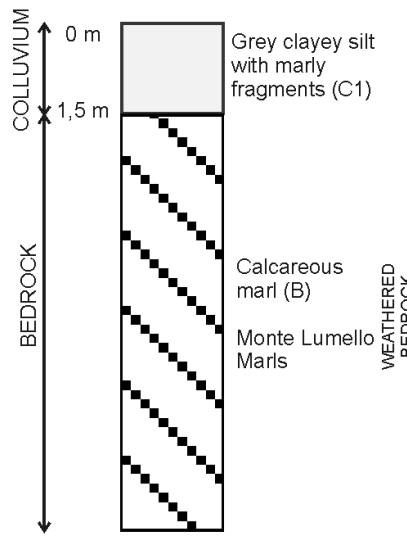

$\mathrm{Cl} 1$

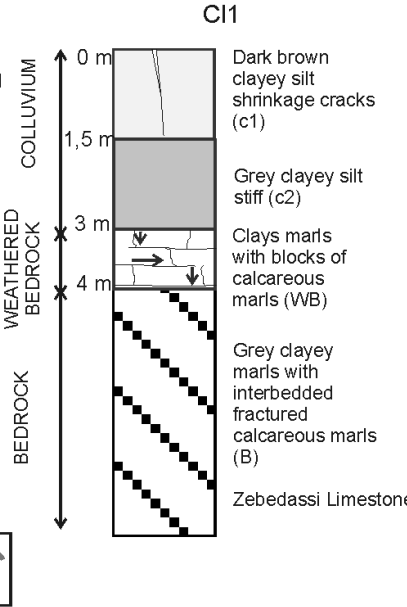

Slf
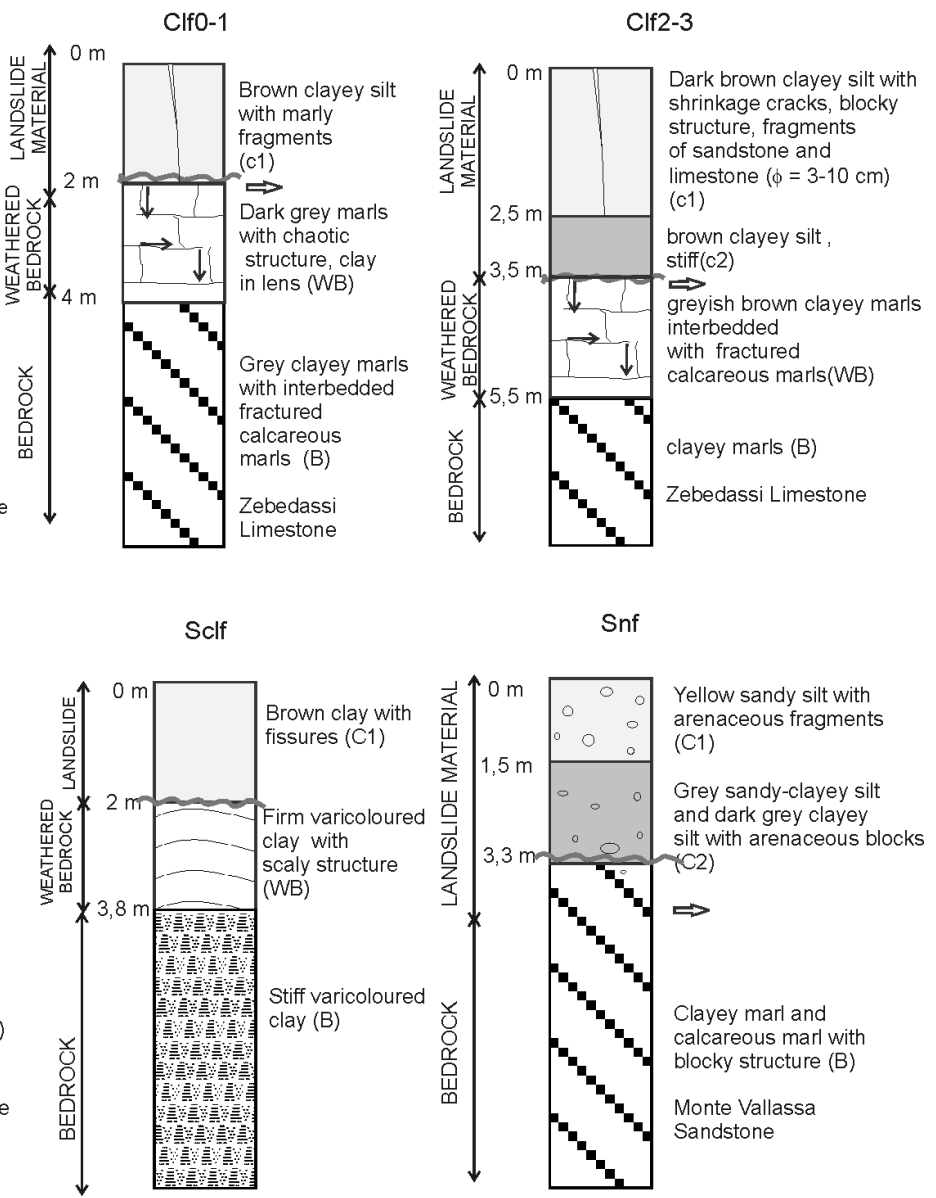

Fig. 4. Lithological profiles of the main engineering geological units. 1: sliding surface; 2: ground-water flow.

Units $\mathrm{cl}, \mathrm{scl}$ and sl correspond to the weathering material of Zebedassi Limestone, Monte Piano Formation and Monte Lumello Formation respectively and are mainly clays with marly and calcareous fragments (Fig. 5). They can be distinguished in the succession into horizons $\mathrm{C} 1, \mathrm{C} 2$ and sometimes C3 (unit sl) which correspond to completely weathered bedrock in which the original structures have been obliterated. Where slope instabilities are present (units clf, sclf and slf) the horizons $\mathrm{C} 2$ and $\mathrm{C} 3$ indicate landslide material of different age. The horizon WB represents the partially altered bedrock and $\mathrm{B}$ the unaltered bedrock. Slope angles range between $6^{\circ}$ and $12^{\circ}$.

Units cl-clf, and scl-sclf cover respectively the $70 \%$ and the $15 \%$ of the study area, the colluvial material range in depth up to more than $4 \mathrm{~m}$ (clf). The colluvial soils of units clf and sclf are organized in macro-aggregates which often contain sliding surfaces with slickensides (Fig. 5b). Often within the clay matrix there are stony clasts (marl, limestone, sandstone) with sharp edges. Swelling-shrinking phenomena are well documented by the presence of slickensides, shrinkage fissures well developed in the horizon $\mathrm{C} 1$ and sometimes $\mathrm{C} 2$ and a blocky structure. The bedrock of units $\mathrm{cl}$ and clf consists in fractured calcareous marls with interbedded shales and clays (Fig. 5a). It has layers with permeability contrasts that dip in the slope. The bedrock of unit scl and sclf consists in stiff varicoloured clays, with a scaly structure. All slides are shallow, less than $3 \mathrm{~m}$ in depth and classified as translational failures often evolving into earth flow, with the failure surface located along the contact between the colluvium and the underlying weathered bedrock. Earth flow developed in the unit sclf.

Units sl and slf represent the $10 \%$ of the study site; the structure of colluvial soils shows no preferential shear planes and is often friable to handle. In unit slf instabilities are translational in nature, they sometimes interest the weathered bedrock and sliding surfaces are present at depth up to $3 \mathrm{~m}$.

\subsection{Hydrogeological characteristics of the colluvial soils and the bedrock}

The stability conditions of the slopes are governed by the complex hydrogeological situation, in particular by the ground water circulating in the sandstone slab (Monte Vallassa Sandstone), sustained by the impermeable clayey and marly substratum. 

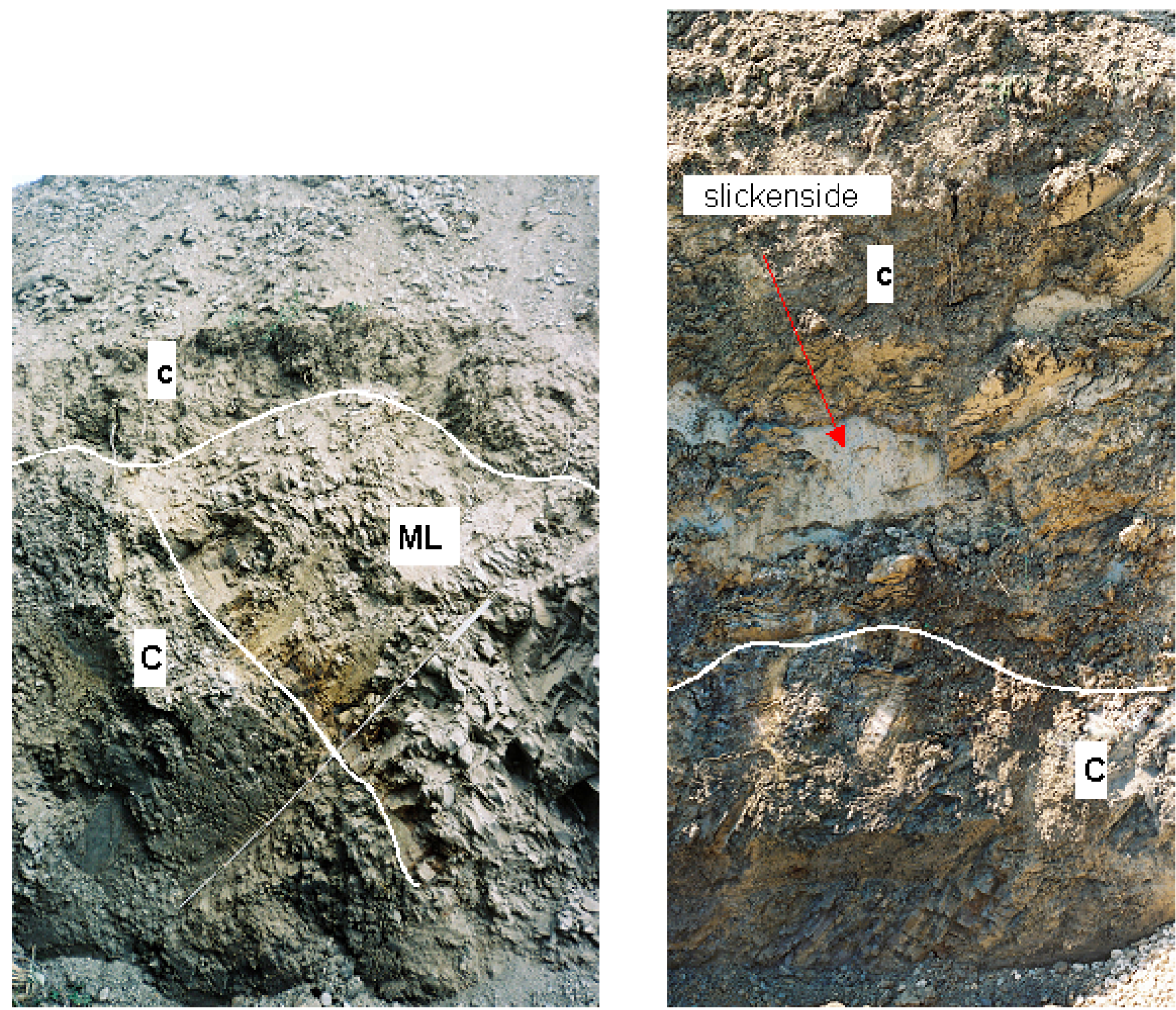

Fig. 5. Photos showing the soil profile of unit cl. c: colluvium; C: shale and clays (bedrock); ML: calcareous marls and clay marls (bedrock).

The colluvial soil of unit sn have medium-high hydraulic conductivity. Rainfall infiltrated quickly through these superficial deposits into the bedrock.

Units cl, clf, scl, sclf, sl and slf correspond to colluvial soils with generally low hydraulic conductivity; nevertheless, cracking in the soils due to shrinkage may facilitate water infiltration during rainy periods.

In the units cl, clf, sl and slf, underneath the colluvial deposits at a depth ranging from 2 to $4 \mathrm{~m}$, the weathered bedrock (WB) is highly fractured and ground water flow is taking place through open fractures even in dry season; it has strong fluctuations, overall during the rainy season. The unaltered bedrock exhibit high spatial variability and the occurrence of alternate layers of permeable and impermeable materials might yield water tables at various depths.
In the units scl, sclf the colluvial soils with a secondary permeability due to the shrinkage overlaid an impermeable bedrock.

\subsection{Geotechnical characteristics of the colluvial soils}

On the basis of grain-size distribution, the colluvial soils were classified as sandy clayey silt (snf) and sandy silt (sn), silty clay and clayey silt (cl, clf), clayey silt (sl, slf) and clay (scl, sclf). Units scl, sclf contained the highest amount of clay $(>70 \%)$, while unit sn had the lowest clay content $(<35 \%)$.

A plot of Atterberg limits on Casagrande plasticity chart (Fig. 6) shows that the fine-grained portion of colluvial soils can be classified as $\mathrm{CL}$ (sn, snf, sl), $\mathrm{CH}$ (cl, clf) and $\mathrm{OH}-\mathrm{MH}$ (slf and scl). 


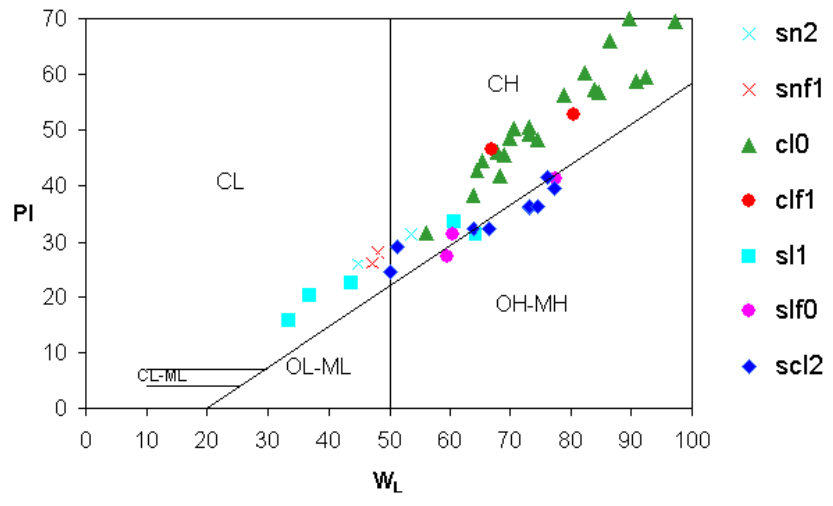

Fig. 6. Plasticity chart.

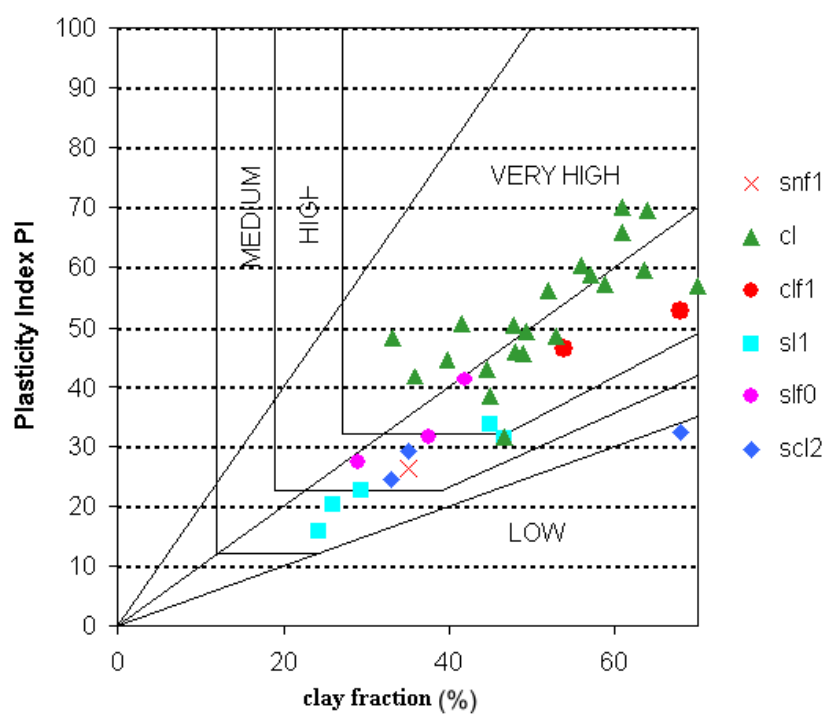

Fig. 7. Distribution of the investigated samples on activity and swell potential chart proposed by Williams and Donaldson (1980).

The values of blue determined with the methylene blue dye adsorption are very high for the unit $\mathrm{cl}$ and clf (6$11.5 \mathrm{~g} / 100 \mathrm{~g}$ of soil for cl; $6.5-8 \mathrm{~g} / 100 \mathrm{~g}$ of soil for clf) and indicate that for these soils expansive lattice-type minerals are the most likely clay minerals present.

The colluvial soils of units cl, clf, scl and slf present a high to very high swelling/shrinking potential following the classification chart of Williams and Donaldson (Fig. 7).

The geotechnical soil profiles do not highlight significant geotechnical differences with depth between the colluvium of unit sn, scl and sl; generally the horizons $\mathrm{C} 1$ and $\mathrm{C} 2$ are more plastic and contain more clay fraction than the weathered bedrock and the bedrock. Geotechnical profiles in unit cl show also homogeneity of index properties and clay content (Figs. 8-9). Little differences concern the horizons C2 and WB which have clay fraction and plasticity smaller than $\mathrm{C} 1$ (more weathered) and the bedrock B.

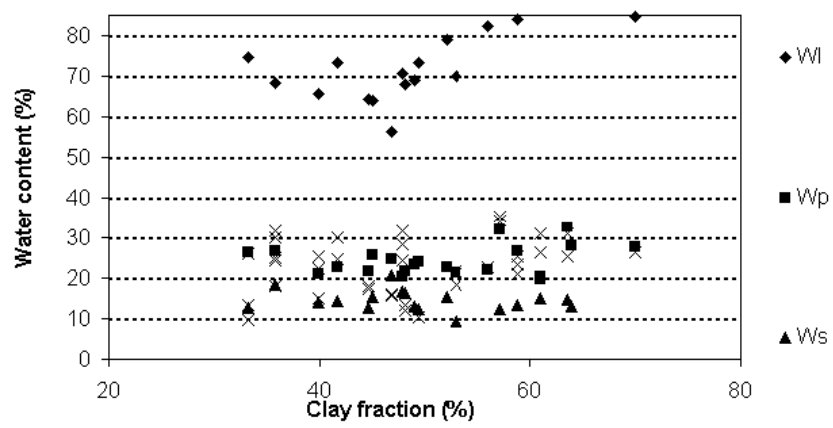

Fig. 8. Clay content, Atterberg limit (Wl: liquid limit; Wp: plastic limit; Ws: shrinkage limit) and natural water content (w) of the samples of units cl.

A comparison of Atterberg limits with natural water content for soils of unit $\mathrm{cl}$, collected during the drought period August-September 2003, shows that, even in these conditions, the water content is between the plastic limit and the shrinkage limit (Fig. 8). The water content is lower than the shrinkage limit only for the top $0.5-0.8 \mathrm{~m}$, where the soil has an intense state of desiccation. A lot of samples with water content higher than the plastic limit correspond to the horizon WB (weathered bedrock), below the slide surface, where water table is often present.

The soils are saturated or quasi-saturated $(\mathrm{Sr}>=85 \%)$ even in drought periods, as August-September 2003. Non saturated conditions characterize only the upper layer of the soil profile (horizons $\mathrm{C} 1$ ). Water content increases with depth and the matric suction decreases. The active zone, determined through the measure of the soil suction, is up to $0.8-2.5 \mathrm{~m}$ deep in relation with the thickness of the soil (Table 1 and Fig. 9).

The range of overall shrinkage limit is very high (9-22\%) and there is a clear correlation with the clay content and the presence of expansive lattice-type minerals as indicated by VB. Values of shrinkage limit range from 16 and $22 \%$ for unit sl, sn. The lowest values (9-15\%) correspond to the horizon $\mathrm{C} 1$ of unit $\mathrm{cl}$ and scl.

In clay soil the structure changes with the water content due to the swell-shrink dynamics of the material (Vogel et al., 2005). Fiorillo and Guadagno (2000) underline also the important role played in the reactivations of landslides by the dry seasons preceding rainy periods. Particularly dry periods can cause a deeper cracking in the soils, which may facilitate water infiltration during rainy periods. The network of shrinkage cracks brings an essential contribution to the hydraulic conductivity of a soil and therefore to mass movements. For this reason the geometrical characteristics of cracks network in swelling soils are of great interest and were investigated in the drought period August-September 2003. The superficial soils of unit $\mathrm{cl}$ and scl (horizon $\mathrm{C} 1$ ) were heavily fissured. Shrinkage cracks were near-vertical; they extended almost to the depth of seasonal moisture change in 

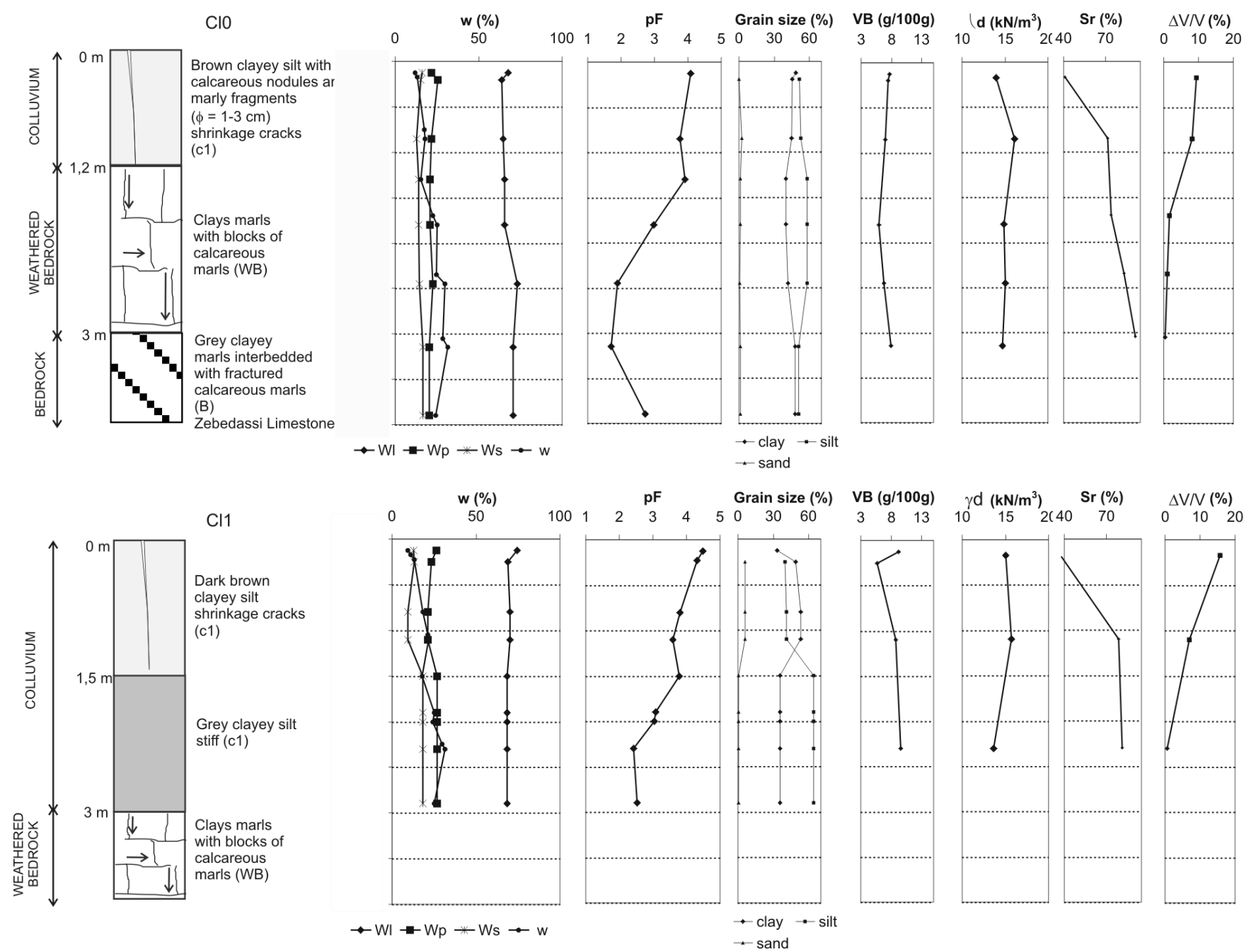

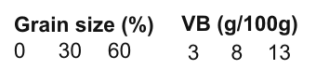
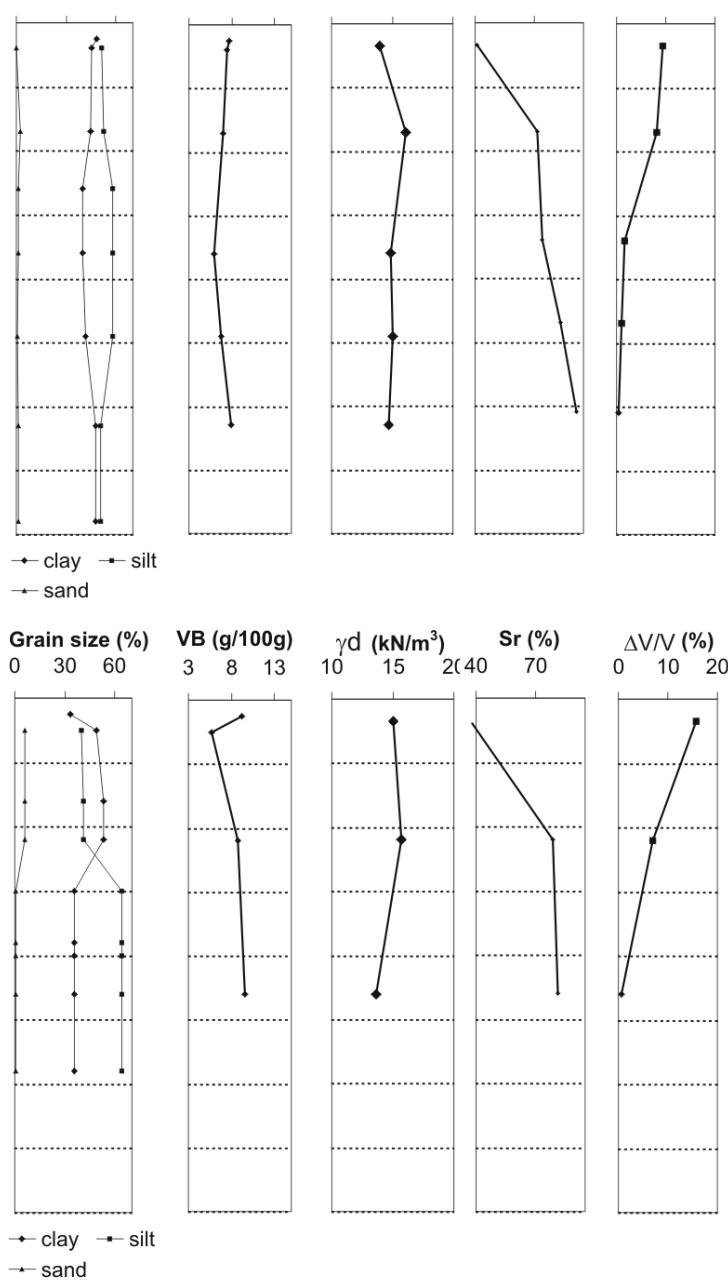

Fig. 9. Geotechnical profiles of unit cl. pF: soil suction; w: natural water content; Wl: liquid limit; Wp: plastic limit; Ws: shrinkage limit; VB: value of blue; $\gamma$ d: dry density; e: void ratio; Sr: degree of saturation; S: swell strain.

Table 2. Geotechnical characteristics of the samples subjected to the swell strain determination.

\begin{tabular}{|c|c|c|c|c|c|c|c|c|c|c|c|c|c|c|}
\hline Unit & Sample & Depth (m) & $\mathrm{C}(\%)$ & Wl & $\mathrm{Wp}$ & Ws & IP & $\begin{array}{l}\text { VB } \\
(\mathrm{g} / 100 \mathrm{~g} \text { of } \\
\text { soil })\end{array}$ & $\mathrm{w}(\%)$ & $\begin{array}{l}\gamma \mathrm{d} \\
\left(\mathrm{kN} \backslash \mathrm{m}^{3}\right)\end{array}$ & $\mathrm{e}$ & $\operatorname{Sr}(\%)$ & $\mathrm{pF}$ & $\Delta \mathrm{V} / \mathrm{V}(\%)$ \\
\hline \multirow{5}{*}{$\mathrm{cl0}$} & A1 & 0.1 & 48 & 67.9 & 21.8 & 16.4 & 46.1 & 7.7 & 12.81 & 14.64 & 0.84 & 41 & 4.1 & 9.4 \\
\hline & $\mathrm{A} 2$ & 0.75 & 45 & 64.5 & 21.6 & 12.7 & 42.9 & 7.0 & 17.90 & 16.13 & 0.67 & 72 & 3.8 & 8.2 \\
\hline & A3 & 1.7 & 39 & 65.5 & 21.0 & 14.1 & 44.5 & 5.9 & 22.38 & 14.85 & 0.82 & 74 & 3.9 & 1.62 \\
\hline & A4 & 2.3 & 42 & 73.3 & 22.7 & 14.3 & 50.6 & 6.7 & 24.68 & 15.01 & 0.80 & 84 & 1.9 & 1.04 \\
\hline & A5 & 3.0 & 48 & 70.8 & 20.4 & 16.7 & 50.4 & 8.0 & 28.49 & 14.65 & 0.84 & 91 & 1.7 & 0.3 \\
\hline \multirow{4}{*}{ cl1 } & B1 & 0.2 & 33 & 74.6 & 26.2 & 12.6 & 48.3 & 9.2 & 10.97 & 14.98 & 0.80 & 37 & 4.3 & 15.8 \\
\hline & B2 & 1.0 & 53 & 70.1 & 21.5 & 9.2 & 48.6 & 8.8 & 21.07 & 15.67 & 0.72 & 79 & 3.6 & 7.0 \\
\hline & B3 & 2.2 & 36 & 68.5 & 26.6 & 18.2 & 41.9 & 9.6 & 29.88 & 13.55 & 0.99 & 81 & 2.4 & 0.7 \\
\hline & $\mathrm{C}$ & 0.3 & 49 & 73.3 & 23.9 & 12.4 & 49.4 & 8.7 & 7.23 & 18.49 & 0.46 & 42 & 4.3 & 23.1 \\
\hline
\end{tabular}




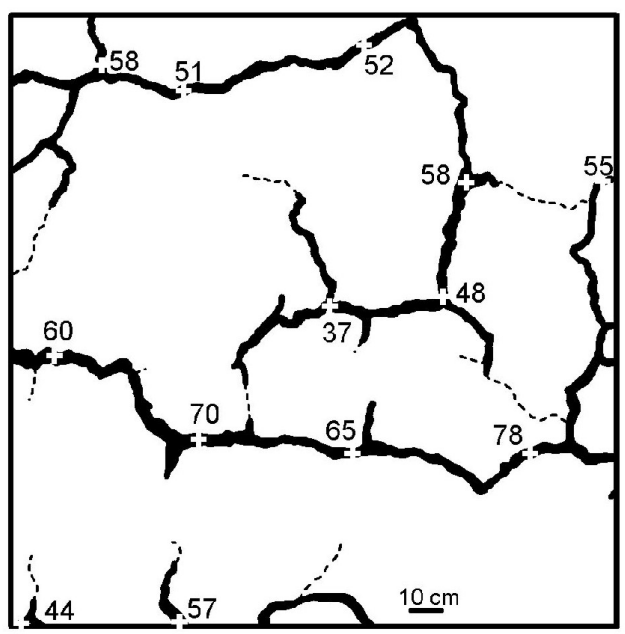

a)

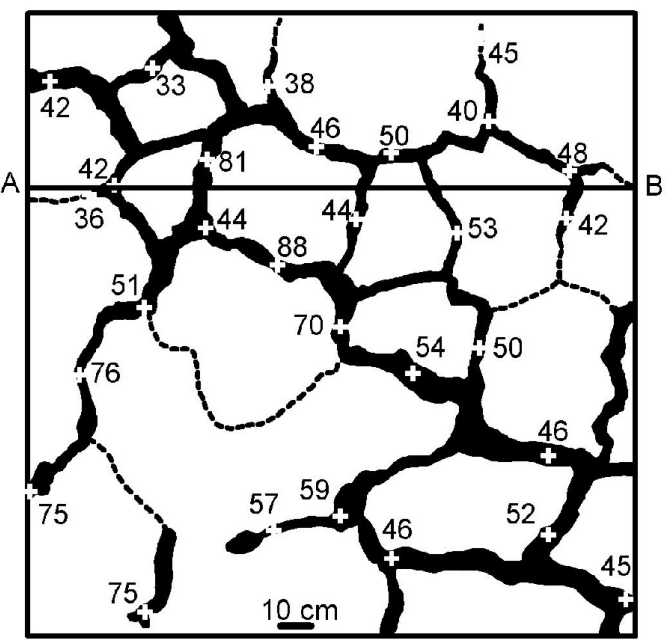

b)

A

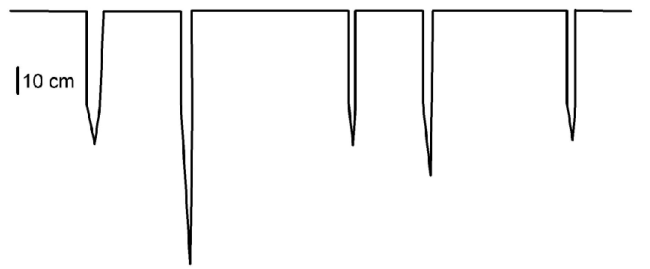

C)

Fig. 10. Crack pattern at the soil surface of unit cl. (a) soil with grass; (b) soil ploughed in spring; (c) cross-section showing the crack depth.

the ground (1.4 and $1.9 \mathrm{~m}$ for unit $\mathrm{cl})$. The soil was so desiccated that the fissures are wide open till a depth of $0.5-0.8 \mathrm{~m}$, where the soils are unsaturated and the water content is below the shrinkage limit (Fig. 10). The water table is below this depth. The horizontal shrinkage SLo was measured in the field for unit $\mathrm{cl}$ which represent the soils with the highest swell strain

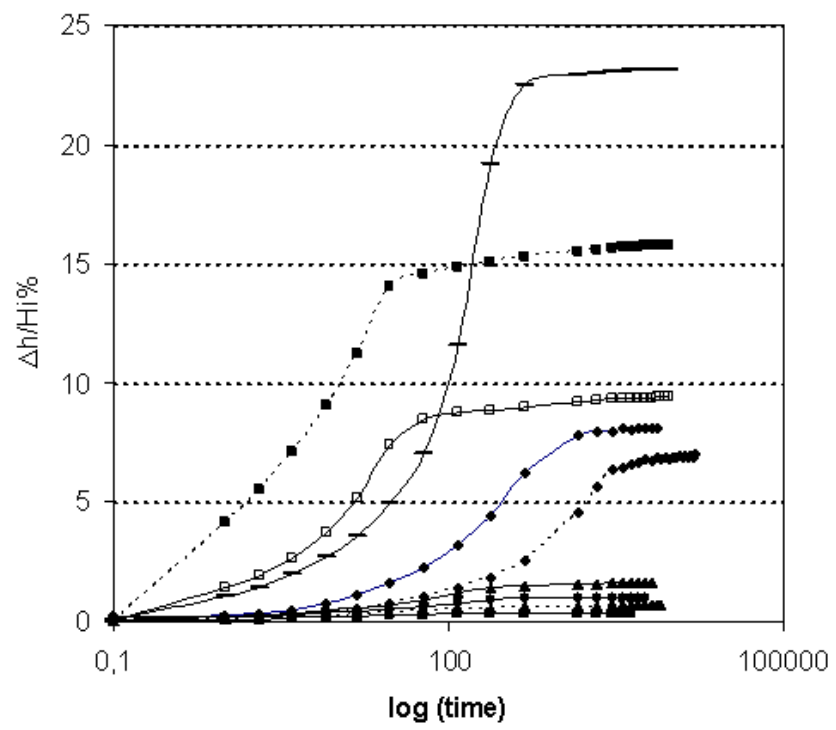

$\longrightarrow \mathrm{A} 1 \longrightarrow \mathrm{A}_{2} \longrightarrow \mathrm{A} 3 \longrightarrow \mathrm{A}_{4} \longrightarrow \mathrm{A} 5 \cdots \boxminus \cdots \mathrm{B} 1$
$\cdots \cdots \cdots \mathrm{B} 2 \cdots \cdots \mathrm{B} \longrightarrow \mathrm{C}$

Fig. 11. Swell strain measured in laboratory for samples of unit cl (Table 1).

swelling-shrinking potential. SLo was calculated as follows:

$\mathrm{SL} 0=\mathrm{Sv} / \mathrm{St} \times 100$

where: $\mathrm{Sv}$ is the surface area of cracks; $\mathrm{St}$ is the surface area of the soil before the shrinkage.

The horizontal shrinkage ranges from 3.4 to $18 \%$ (Fig. 10), strongly in relationship with the landuse and the drainage conditions. The lowest value (3.4\%) (Fig. 10a) corresponds to a soil with grass (unit cl0), a slope angle of $11^{\circ}$ and a good drainage. The highest values (10.8 and 18\%) (Fig. 10b) are associated to soil ploughed in the spring of the year 2003, with a slope angle of $6-8^{\circ}$ and a poor drainage (unit cl1). The suction pressure associated with the onset of cracking is approximately $4-4.5 \mathrm{pF}$ (the highest suction occurs nearest the cracks).

Large heave movements can occur when the desiccated clay soils, collected during the drought period, were wetted. The percentage of heave decreases with depth in relationship with the increase of water content and the degree of saturation (Table 2). The swell strain ranges from 7 to $23 \%$ in the active zone of unit cl (Fig. 11).

\section{Discussion and conclusions}

The lithological and geotechnical characteristics of clayey colluvial soils, derived by the weathering of the bedrock and downslope transportation, of a test area in Northern Apennines were analysed. 
A method is proposed to map these soils; it is based on the integration of intensive field work together with laboratory tests, in order to define areas that may be regarded as homogeneous from the geomorphologic and engineering geological point of view in terms of shallow slope instability. The mapping units were defined as engineering geological units, it means areas in which the considered parameters (slope angle, landslide occurrence, lithology of the rock substrate, grain size, structure, thickness, hydrogeological and geotechnical characteristics of the colluvial soils) are assumed to be uniform.

Shallow landslides were related to the different colluvial soils of the area. The engineering geological units correspond to different type of shallow slope movements: complex slide (translational slide evolving in earth flow) in unit cl and clf, earth flow in unit scl, sclf, cl and clf, and translational slide in unit sl and slf.

The area is characterized by shallow landslides which develop in the clay colluvial soils at the contact between the colluvium and the partially weathered bedrock. The instability predisposing factors are represented by the poor geotechnical properties of the colluvial material (high plasticity, high clay fraction and high content of expansive lattice-type minerals which affect the strength properties of the colluvium), the ground water flow in the weathered bedrock, the landuse. The swelling/shrinkage of clay soils appears to be a very important factor in the localisation of landslide phenomena. The majority of the landslides occurred on slopes characterized by colluvial soils (unit clf and sclf) with high to very high swelling-shrinking potential. There are not significant variations of the geotechnical properties in the soil profiles, but the swelling and shrinkage present large variations with depth in relationship with the water content and degree of saturation. Result obtained from the present analysis reveal the necessity to characterize the shrinkage and swelling phenomena in the study of shallow instability. Horizontal shrinkage in drought periods was very strong and reached the $18 \%$ in recently ploughed soils. The desiccation cracks that open up during such a period provide a route for water from subsequent rainfalls to enter the ground up to 1.4-1.9 m (active zone depth in unit $\mathrm{cl}$ ). The process of shrinkage causes cracks, which on re-wetting, do not close-up perfectly and hence cause the soil to bulk-out slightly, and also allow access to water. When material falls into cracks the soil is unable to move back causing enhanced swelling pressure with the formation of slickenside.

The methodology is useful for studies at a local scale (1:10000 and 1:5000) and requires a deep knowledge of the lithological and geological characteristics of the area. The work is a starting point for modelling hydrogeological and geotechnical processes responsible for slope instability and for the assessment of shallow slide susceptibility. The engineering-geological units are also useful for swellingshrinkage susceptibility assessment.
Edited by: D. Calcaterra

Reviewed by: M. Jaboyedoff and another referee

\section{References}

AFNOR: Mesure de la quantité et de l'activité de la fraction argileuse: determination de la valeur de bleu de méthylène d'un sol par l'essai a la tache. Norme française homologuée, NF P94068 (in French), 1998.

ASTM: Annual book of ASTM Standards, ASTM Publication, Philadelphia, USA, 1994.

Beatrizzotti, G., Bellinzona, G., Beltrami, G., Boni, A., Braga, G., Marchetti, G., and Mosna, S.: Geological map of Italy Fg.71 Voghera (2nd Ed) - Servizio Geologico d'Italia, Roma, 1969.

Braga, G., Braschi, G., Calculli, S., Caucia, F., Cerro, A., Colleselli, F., Grisolia, M., Piccio, A., Rossetti, R., Setti, M., Spalato, A., Soggetti, F., and Veniale, F.: I fenomeni franosi nell'Oltrepo Pavese: tipologia e cause, Geologia Applicata e Idrogeologia, 20, 621-666, 1985.

Calvello, M., Lasco, M., Vassallo, R., and Di Maio, C.: Compressibility and residual shear strenght of smectitic clays: influence of pore aqueous solutions and organic solvents, Italian Geotechnical Journal, 1, 34-46, 2005.

Chandler, R. J. and Gutierrez, C. I.: The filter paper of suction measurement, Géotechnique, 36, 265-268, 1986.

Chiappone, A. and Scavia, C.: La prova al blu di metilene nella caratterizzazione geotecnica: un'applicazione allo studio della stabilità dei versanti, Italian Geotechnical Journal, 4, 36-51, 1999.

Cruden, D. and Varnes, D. J.: Landslide types and processes, Landslides, investigation and mitigation, Special Report, 247, edited by: Turner, A. K. and Schuster, R. L., 1996.

Esu, F.: Behaviour of slopes in structurally complex formations, Int. Symp. the geotechnics of structurally complex formations, 1, 292-303, 1977.

Fiorillo, F. and Guadagno, F. M.: Analysis of rainfall patterns triggering reactivations od a large landslide in Pleistocene clay in Molise (Italy), Landslide in research, theory and practice, 2, 553558, Thomas Telford, London, 2000.

Magnan, J. P. and Youssefian, G.: Essai au bleu de méthylène et classification géotechnique des sols, Bull. Liaison Labo P. et Ch., 159, 93-104, 1989.

Meisina, C.: Swelling-shrinking properties of weathered clayey soils associated with shallow landslides, Quat. J. Engi. Geology and Hydrogeology, 37, 77-94, 2004.

Picarelli, L.: Mechanisms and rates of slope movements in fine grained soils, GeoEng2000, 1, 1618-1670, 2000.

Rossetti, R. and Ottone, C.: Esame preliminare delle condizioni pluviometriche dell'Oltrepo Pavese e dei valori critici delle precipitazioni in relazione ai fenomeni di dissesto franoso, Geologia Applicata e Idrogeologia, 14, 83-99, 1979.

Swarbrick, G. E.: Measurement of soil suction using the filter paper method, Proc. Of the First Int. Conf. on Unsaturated soils, Paris, 2, 653-658, 1995.

Turner, A. K.: Colluvium and talus, Landslides, investigation and mitigation, Special Report, 247, edited by: Turner, A. K. and Schuster, R. L., 1996. 
Vogel, H. J., Hoffmann, H., and Roth, K.: Studies of crack dynamics in clay soil. 1. Experimental methods, results, and morphological quantification, Geoderma, 125, 203-211, 2005.
Williams, A. B. and Donaldson, G. W.: Developments relating to Building on expansive soils in South Africa: 1973-1980, Proc. of the 4th Int. Conf. On Exp. Soils, Denver, 2, 834-844, 1980. 